\title{
Kousseff syndrome
}

INSERM

\section{Source}

INSERM. (1999). Orphanet: an online rare disease and orphan drug data base. Kousseff syndrome. ORPHA:2351

Kousseff syndrome is characterized by the association of conotruncal heart defects, myelomeningocele and craniofacial dysmorphism similar to that seen in monosomy 22 q11 (see this term). 